\title{
Une histoire de fous!
}

Les Hôpitaux universitaires de Genève. Rapport d'activité.

Leur ultime patron le dit.

De 1900 à 2000:

- diminution de 17,8\% des lits;

- diminution de $13 \%$ des journées d'hospitalisation;

- diminution de $4 \%$ du nombre de postes.

mais,

augmentation de 22\% du budget des hôpitaux!

Question: Pour faire baisser le budget, faut-il alors augmenter les lits, les journées d'hospitalisation et le nombre de postes?

Parlez-en à vos parlementaires préférés, qui, tous les jours, redécouvrent la roue.

La roue est faite pour déjouer le cahot, non pas pour conduire au chaos.

Dr Claude Aubert, membre du CC de la FMH 